\title{
ERRATUM
}

\section{Erratum to: Gastric injuries during gynaecologic laparoscopy}

\author{
Lucio Cipullo • Fulvio Zullo • Federica Visconti • \\ Valeria Palatucci • Renato Pascale • \\ Maria Luisa Marra $\cdot$ Maurizio Guida
}

Published online: 20 June 2012

(C) Springer-Verlag 2012

\section{Erratum to: Arch Gynecol Obstet}

DOI 10.1007/s00404-012-2389-0

Unfortunately, the first and surnames of the complete author group has been swapped in the online publication of the article. The correct listing of the author group is given below.

Lucio Cipullo · Fulvio Zullo · Federica Visconti · Valeria Palatucci · Renato Pascale · Maria Luisa Marra · Maurizio Guida

The online version of the original article can be found under doi:10.1007/s00404-012-2389-0.

L. Cipullo · F. Zullo · F. Visconti · V. Palatucci - R. Pascale .

M. L. Marra $\cdot$ M. Guida $(\square)$

Department of Gynaecology and Obstetrics,

University of Salerno, Largo Città di Ippocrate,

Salerno, Italy

e-mail: maguida@unisa.it 